\title{
The Role of External Knowledge Sources and Organizational Design in the Process of Opportunity Exploitation
}

Foss, Nicolai Juul; Lyngsie, Jacob; A. Zahra, Shaker

Document Version

Final published version

Publication date:

2013

License

CC BY-NC-ND

Citation for published version (APA):

Foss, N. J., Lyngsie, J., \& A. Zahra, S. (2013). The Role of External Knowledge Sources and Organizational Design in the Process of Opportunity Exploitation. Copenhagen Business School [wp]. SMG Working Paper Vol. 2013 No. 6

Link to publication in CBS Research Portal

\section{General rights}

Copyright and moral rights for the publications made accessible in the public portal are retained by the authors and/or other copyright owners and it is a condition of accessing publications that users recognise and abide by the legal requirements associated with these rights.

\section{Take down policy}

If you believe that this document breaches copyright please contact us (research.lib@cbs.dk) providing details, and we will remove access to the work immediately and investigate your claim. 
The Role of External Knowledge Sources and Organizational Design in the Process of Opportunity Exploitation

Nicolai J. Foss

Jacob Lyngsie

Shaker A. Zahra

\section{SMG WP 6/2013}

April, 2013 
SMG Working Paper No. 6/2013

April, 2013

ISBN: 978-87-91815-88-1

Department of Strategic Management and Globalization Copenhagen Business School

Kilen, Kilevej 14A

2000 Frederiksberg

Denmark

www.cbs.dk/smg 


\title{
THE ROLE OF EXTERNAL KNOWLEDGE SOURCES AND ORGANIZATIONAL DESIGN IN THE PROCESS OF OPPORTUNITY EXPLOITATION
}

\author{
Nicolai J. Foss \\ Department of Strategic Management and Globalization \\ Copenhagen Business School; Kilevej 14, $2^{\text {nd }}$ floor \\ 2000 Frederiksberg; Denmark \\ njf.smg@cbs.dk \\ and \\ Department of Strategy and Management \\ Norwegian School of Economics and Business Administration \\ Breiviksveien 40, N-5045 \\ Bergen; Norway \\ Jacob Lyngsie \\ Department of Strategic Management and Globalization \\ Copenhagen Business School; Kilevej 14, $2^{\text {nd }}$ floor \\ 2000 Frederiksberg; Denmark \\ jl.smg@cbs.dk \\ Shaker A. Zahra \\ Strategic Management \& Organization Dept \\ Carlson School of Management [Suite 3-430] \\ University of Minnesota \\ Minneapolis, MN 55455-040; USA \\ zahra004@umn.edu
}

April 10, 2013

Forthcoming, Strategic Management Journal

\section{Acknowledgments}

We thank Christian Geisler Asmussen, Sarah Park, Nils Stieglitz and two anonymous reviewers for comments on earlier versions of this paper.

Keywords: Strategic entrepreneurship, innovation, external knowledge, organizational design.

JEL Codes: D21, L23, L26, M1, O31 


\title{
THE ROLE OF EXTERNAL KNOWLEDGE SOURCES AND ORGANIZATIONAL DESIGN IN THE PROCESS OF EXPLOITING STRATEGIC OPPORTUNITIES
}

\begin{abstract}
Research highlights the role of external knowledge sources in the recognition of strategic opportunities, but is less forthcoming with respect to the role of such sources during the process of exploiting or realizing opportunities. We build on the knowledge-based view to propose that realizing opportunities often involves significant interactions with external knowledge sources. Organizational design can facilitate a firm's interactions with these sources, while achieving coordination among organizational members engaged in opportunity exploitation. Our analysis of a double-respondent survey involving 536 Danish firms shows that the use of external knowledge sources is positively associated with opportunity exploitation, but the strength of this association is significantly influenced by organizational designs that enable the firm to access external knowledge during the process of exploiting opportunities.
\end{abstract}

Keywords: Strategic entrepreneurship, opportunity exploitation, organizational design, knowledge-based view. 


\section{INTRODUCTION}

The knowledge-based view (KBV) highlights the central role of knowledge in the creation of strategic opportunities that represent new potential sources of revenue (Zahra and George, 2002; Denrell, Fang and Winter, 2003: 979). Much recent research suggests that external knowledge can be an important source of such opportunities (e.g., Chesbrough, 2003; Laursen and Salter, 2006; Nambisan and Swahney, 2007). This study examines: (1) the role of external knowledge sources in the process of exploiting strategic opportunities, and (2) the influence of a firm's organizational design on the effect of external sources on opportunity exploitation, that is, the deployment of resources, actions, and investments to realize recognized opportunities (see Foss and Klein, 2012). Interactions with external knowledge sources may expedite opportunity exploitation. Thus, external knowledge sources matter not only in the recognition of strategic opportunities but also in their exploitation. We propose that several factors encourage firms to tap outside sources and gain useful knowledge while exploiting opportunities, notably the firm's need to access complementary external expertise to help solve novel problems associated with novel strategic opportunities as a main motivation. Based on this reasoning, we propose that the intensity with which the firm uses external knowledge sources during the process of opportunity exploitation is positively associated with its actual opportunity exploitation

We also argue that firms' organizational designs can significantly facilitate their interactions with external knowledge sources in opportunity exploitation (Teece, 1998). Foss, Laursen, and Pedersen (2011) find that a higher degree of delegation makes it easier for firms to access the knowledge held by customers, and that other organizational practices support the use of knowledge inside firms once that knowledge has crossed their boundaries. However, Foss et al.'s (2011) study focuses on early contacts with customers and ignores subsequent interactions. In contrast, we advance the hypothesis that an important role of organizational design is to ensure that relevant individuals in the firm are empowered to cooperate with external parties during exploitation. 
However, the organizational design must also address the internal coordination needs that arise when the firm engages different external parties during opportunity exploitation. The need to meet both demands requires an organizational design that simultaneously enables decentralization and ensures that decentralized efforts are coordinated during opportunity exploitation. We thus posit a significant three-way interaction, such that opportunity exploitation is highest when the use of external knowledge sources, and the extent of decentralization and coordination are high. Our empirical analysis draws on double-respondent data collected from 536 Danish private firms. After controlling for several factors, we find that the use of external knowledge sources is positively associated with opportunity exploitation and that the strength of this association is influenced by the organizational design of the firm.

\section{THEORETICAL BACKGROUND: STRATEGIC OPPORTUNITIES AND THE ROLE OF EXTERNAL KNOWLEDGE SOURCES}

\section{External knowledge and the recognition of strategic opportunities}

Companies are under pressure to develop new revenue sources. Internal innovation (e.g., as driven by R\&D) is a key source of new revenue streams. With intensifying global competition, the dispersion of knowledge around the globe, and the need for fast development cycles, companies find external sources of knowledge useful in filling gaps in their product and business portfolios, and in upgrading the R\&D capabilities. These external sources are vital for recognizing opportunities of all kinds, including not just product and process innovations, but also new markets and organizational structures (Schumpeter, 1912), as well as new contractual designs (Mayer and Argyres, 2004; Michael, 2003, 2007), arbitrage opportunities (Kirzner, 1973), suppliers (Rumelt, 1987), buyers (Oviatt and McDougall, 2005), complementors (Brandenburger and Stuart, 1996), and management processes (Mol and Birkinshaw, 2009). Thus, research stresses the role of pre-existing knowledge bases (e.g., at the industry level) for entrepreneurial start-ups (Cooper, 1973; Audretsch, Lehmann and Warning, 2005), and suggests that 'a context with more knowledge will generate more 
entrepreneurial opportunities. By contrast, a context with less knowledge will generate fewer entrepreneurial opportunities' (Audretsch \& Keilbach, 2007: 1242). In such contexts, start-ups as well as established firms may create breakthrough opportunities in the form of innovations by experimenting with novel, emerging, and pioneering technologies (Ahuja and Lampert, 2001; see also Schumpeter, 1912; Venkataraman, 1997). In addition to exploiting existing external knowledge bases in greater depth, firms may need to extend their search scope by exploring new external knowledge sources (Katila and Ahuja, 2002), such as suppliers, customers, or universities (Cassiman and Veugelers, 2002; Chesbrough, 2003; Nambisan and Swahney, 2007). For example, Laursen and Salter (2006) show that the two most important external sources of knowledge inputs for innovation among UK firms are 'suppliers' and 'clients or customers.' Evolutionary economics (Nelson and Winter, 1982) and research on knowledge spillovers (Cassiman and Veugelers, 2002; Audretsch and Keilbach, 2007) also indicate that strategic opportunities emerge from the interplay between firmspecific capabilities and the use of external knowledge. In sum, a key insight from extant research is that different opportunities may result from interactions with various external parties (e.g., von Hippel, 1976, 1988; Shane, 2000; Chesbrough, 2003; Laursen and Salter, 2006), often in an interactive, non-linear, multi-stage process (Kline and Rosenberg, 1986; Henkel and von Hippel, 2005).

\section{External knowledge and the process of exploiting strategic opportunities}

While the role of external knowledge sources in prompting the recognition of new strategic opportunities has been extensively examined, the extant literature is less forthcoming about the role of such knowledge sources beyond the opportunity recognition phase. In general, research suggests that external resources may be crucial for exploiting strategic opportunities. Thus, firms in the exploitation phase need to mobilize complementary assets (e.g., production, sales, and marketing) in a focused manner (Teece, 1986). We argue that some of the external knowledge sources engaged during the opportunity recognition phase may naturally be involved in the exploitation phase. 
Moreover, firms may also need to engage external knowledge sources for the first time or tap into different external knowledge sources during the exploitation phase. For example, engaging in 'technical dialogue' (Monteverde, 1995) with specialized external suppliers of technical assistance may be entirely different than sourcing 'new ideas' from other external sources. Or, the exploitation of strategic opportunities may call for close collaboration with industry associations, an external source of knowledge not necessarily pivotal to opportunity recognition.

This suggests a need for a more fine-grained understanding of the role of external knowledge sources in strategic entrepreneurship, specifically a recognition that the role of external knowledge sources may often go beyond the opportunity recognition stage and extend to opportunity exploitation. This is an important issue for companies contemplating the use of external sources of knowledge in exploiting opportunities, an issue that has received limited empirical research attention to date. As noted, the extant research often ignores the fact that firms interact with external knowledge sources when exploiting opportunities. It also ignores that these interactions are facilitated and sustained by the firm's organizational design.

\section{THEORETICAL MODEL AND HYPOTHESIS DEVELOPMENT}

In the following, we develop a set of hypotheses on the use of external knowledge sources during the process of realizing opportunities, and the role of organizational design in facilitating this process. Figure 1 summarizes our key constructs and hypotheses.

\section{[Insert Figure 1 here]}

\section{The influence of external knowledge sources on opportunity exploitation}

The knowledge-based strategic management literature emphasizes a linear view of the entrepreneurial process that leaves limited room for interaction with external knowledge sources. Specifically, there are no explicit attempts to link external knowledge sources beyond the recognition stage; thus, contact to such sources seem to cease following the initial act of absorbing external knowledge (Volberda, Foss and Lyles, 2010). However, the realization of opportunities involves 
deploying multiple complementary investments, assets, and actions (Foss and Klein, 2012). Firms may be capable of mobilizing all of these necessary investments, assets, and actions on their own (i.e., full in-house opportunity exploitation), but they typically prefer to acquire some through market or hybrid relations (see Teece, 1986). In the process of exploiting opportunities, firms' connections to outside parties often go beyond sourcing production, sales, and so on (Teece, 1986). Opportunities become manifest in the concrete actions undertaken by firms (Foss and Klein, 2012). These actions are often partly guided by or undertaken in cooperation with external knowledge sources, such as technological service providers, process consultants, organization design consultants, or other outside parties that control knowledge that is useful for eliminating bottlenecks, setting up the right organization, performing sales forecasts, achieving intelligence on competitors, etc., in the process of realizing strategic opportunities.

Roper, Du, and Love (2008: 966) find that 'there is a complementary relationship between internal knowledge generation (i.e. in-plant R\&D) and some external knowledge sourcing' (see also Cassiman and Veugelers, 2002). Even though Roper et al. (2008) have opportunity recognition in mind, a 'complementary relationship' often extends to opportunity exploitation in which firms interact with external holders of important, complementary knowledge. This is likely to be the case when the relevant strategic opportunity is novel and/or complex to the firm and requires the deployment of specialized knowledge. Firms may often not be low-cost suppliers of such knowledge themselves and as a result they get in contact with external sources of the relevant knowledge. Such sources may be specialized suppliers that build capabilities within specific areas of technical advice and consulting services and pool demands for such advice and service (Richardson, 1972; Teece, 1986).

For example, an external knowledge provider, such as a provider of technological services (Arora, 1996; Autio, 1997), may not only be an external impetus for a firm's recognition of a new opportunity (e.g., certain standards or certifications may represent opportunities); it may also help the 
firm to exploit and hone the opportunity by engaging in technical dialogue and direct assistance (Monteverde, 1995). In addition, external knowledge sources can provide useful contextual information that spurs exploitation and determines its outcomes. For example, engaging with industry associations during exploitation may provide a firm with knowledge about industry-specific standards. Interactions with external knowledge sources may also increase the firm's understanding of competitor technologies, organizational designs, and products, thus improving the firm's positioning in its industries. These interactions are useful, and sometimes even necessary for realizing of strategic opportunities.

Strategic opportunities are per definition novel, and realizing them typically requires solving novel problems (Nickerson and Zenger, 2004). Entrepreneurial firms may confront many such problems. Thus, realizing a strategic opportunity in the form of a novel product may require solving novel problems related to prototyping, production, and sales and marketing, as well as novel problems relating to the competitive implications of the product launch and new organizational designs or HRM policies that may be necessitated by the new product (e.g., it may require new KPIs for sales personnel). For many such problems, firms may not have the required capabilities, and therefore benefit from accessing external knowledge sources that can assist in problem solving. Thus, opportunity exploitation depends on the extent to which firms can identify such problems solve them by means of drawing on the relevant external knowledge sources. Based on this reasoning, we offer the following hypothesis:

Hypothesis 1: The extent to which a firm makes use of external knowledge sources beyond the opportunity recognition phase is positively associated with its opportunity exploitation. For completeness, we note that Hypothesis 1 has been anticipated in one existing research streamthe literature on user innovation (von Hippel, 1988, 1998) which shows that users may be involved in the innovation process right up to commercialization. However, interactions with other knowledge 
sources during the process of opportunity exploitation have not, to our knowledge, been treated in the research literature.

\section{External knowledge sources and opportunity exploitation: the role of organizational design}

As firms' interactions with external knowledge sources during opportunity exploitation have received limited empirical attention, the organizational design aspects of this process have not been explicitly addressed. However, extant research (Aldrich and Herken, 1977; Allen, 1977; Cohen and Levinthal, 1990; Nambisan and Swahney, 2007; Zahra and George, 2002; Volberda, Foss, and Lyles, 2010) indicates that several conditions are necessary for external knowledge to be successfully brought into the firm and deployed in the pursuit of strategic opportunities. Such success requires motivated efforts on the part of relevant organizational members (Allen and Cohen, 1969; Nambisan and Swahney, 2007), the use of knowledge already residing within the organization (Cohen and Levinthal, 1990), and the establishment of an organizational setup that allows the right knowledge to reach the right organizational members (Jansen, van den Bosch, and Volberda, 2005; Foss et al., 2011). In other words, attention needs to be directed to to the firm's organizational designs, especially structure.

Extant research identifies several variables along which organizational structure - that is, the 'relatively enduring allocation of work roles and administrative mechanisms that creates a pattern of interrelated work activities' (Jackson and Morgan, 1982: 81)—can be characterized (e.g., Burton and Obel, 2004; Burns and Stalker, 1961; Galbraith, 1974; Miller and Dröge, 1986). These variables include job and unit specialization (with an implied allocation of decision rights, i.e., authority), and coordination by means of (workflow) formalization, rules, targets, and other elements of planning. However, this literature has not been systematically applied to the study of strategic opportunity exploitation.

The two prior research contributions that are most directly related to our study (i.e., Jansen, van den Bosch and Volberda, 2005, and Foss et al., 2011) do not directly link organizational design 
to opportunity exploitation. Still, Jansen et al. (2005) posit that formalization and 'connectedness' (essentially informal communication across functions) are important antecedents of exploitative efforts in general, and they find support for this proposition. Formalization helps in the codification of new knowledge, while connectedness is instrumental in disseminating such new knowledge inhouse, thereby furthering exploitation (Cohen and Levinthal, 1990; Zander and Kogut, 1995). Foss et al. (2011) examine the role of organizational practices in mediating the relationship between knowledge held by users and customers, and firm innovation. They argue that organizational practices of widespread delegation of decision rights, intensive vertical and lateral communication, and incentives for knowledge sharing form a complementary system that fully mediate between externally held knowledge and innovation performance.

Despite the paucity of empirical research, the literature indicates that organizational design can significantly influence the exploitation of strategic opportunities. For example, some evidence implies that the organizational form of multinational corporations influences the extent to which they can pursue entrepreneurship that is rooted in knowledge combination (Birkinshaw, 1997). Research on organizational ambidexterity and its structural components also highlights the critical role of organizational design in successfully bringing about ambidexterity (Simsek, 2009). Finally, research has described 'pro-entrepreneurship organizational architecture' in terms of organizational structures, cultures, and reward systems (Ireland, Covin and Kuratko, 2009). Still, none of this literature explicitly addresses the role of organizational design variables in the context of leveraging external knowledge sources in the process of realizing strategic opportunities.

In general, firms seeking to exploit opportunities need to mobilize complementary assets (production, sales, marketing, etc.) in a focused manner (Teece, 1986), and they frequently use external knowledge sources. The traditional vertically integrated and highly specialized industrial firm with a dedicated R\&D lab has been argued to be a highly efficient institution for opportunity exploitation (Chandler, 1990; Teece, 1992). However, little is known about how firms can use their 
organizational design to facilitate the leveraging of the knowledge of external sources in the opportunity exploitation process. While Jansen et al. (2005) and Foss et al. (2011) address the role of organizational design in absorbing external knowledge in the recognition of opportunities, they do not address its role in leveraging external parties' knowledge in opportunity exploitation. These and similar studies appear to espouse the view that once knowledge has crossed a firm's boundaries, relations to external sources cease. As noted earlier, this view does not reflect actual practices.

Given our observation that firms may involve external knowledge sources even after the opportunity recognition stage and draw on such sources to realize opportunities, the question is: Which organizational designs facilitate the involvement of external knowledge sources in opportunity exploitation? Overall, organizational designs may be described in terms of structure (e.g., delegation, departmentalization, job descriptions) and coordination (e.g., liaison committees, and lateral and vertical communication) (Burton and Obel, 1998). We argue that specific combinations of these variables are required if the firm is to successfully interact with external knowledge sources to effectively exploit strategic opportunities, as depicted in Figure 1.

In any firm, there are several points of contact with external knowledge sources. Indeed, any transaction with the external environment involves contact with a potentially useful knowledge source, and the relevant organizational members serve as potential boundary spanners in terms of bridging the firm and the external knowledge sources. The question is whether the firm's organizational design is supportive of such boundary-spanning activities. In traditional hierarchical structures that imply little delegation of decision rights to employees (Galbraith, 1974; Mendelson, 2000), initiatives and decisions are centralized. Therefore, firms with such structures may find it difficult to act on the identification of relevant external knowledge sources in a timely and efficient manner, and to build relations with these knowledge sources that allow them to gain access to their knowledge. 
The recognition and use of external knowledge sources for opportunity recognition and opportunity exploitation thus often require considerable delegation of decision-making rights. Delegation enables employees to interact with external parties, and to better understand the nature of incoming knowledge and its possible uses. Delegation ensures that local actions are responsive to local knowledge and makes it easier to use such knowledge when exploiting opportunities. In general, efficient delegation co-locates rights to make decisions with those who possess the knowledge about what decisions should (optimally) be made (Jensen and Meckling, 1992); these are not always hierarchical superiors, or centralized functions or departments (Mendelson, 2000). For example, a decentralized structure may allow a middle manager to directly interact with the firm's external technical consultants and resolve problems related to the ramp-up of a new production process for a new product (Monteverde, 1995). As such, delegation facilitates gatekeeping activities (Aldrich and Herker, 1977; Tushman and Katz, 1980) by empowering employees to assume these responsibilities. This reasoning leads to the following hypothesis:

\section{Hypothesis 2: The positive relation between external knowledge sources and opportunity}

$$
\text { exploitation is strengthened when the firm has a decentralized organizational design. }
$$

Even though decentralization may solve the problem of co-locating knowledge and actions, it also creates the problem of how best to coordinate those actions (Dougherty, 2001). The sharing of the knowledge or information transferred into the firm with other parts of the firm is often crucial (Lenox and King, 2004). Foss et al. (2011) observe that this is particularly important when there is a need to transfer knowledge of modifications in a complex technical product that relate to several different components of that product (Baldwin and Clark, 2000).

The realization of opportunities in which feedback loops between different functions and departments are likely requires practices and structures that can facilitate information and knowledge flows. For example, prototyping — an early phase of opportunity exploitation — may reveal problems that call for not only interaction with external knowledge sources but also with internal R\&D 
functions. Similarly, the development of new contractual forms may require the marketing function to interact with customers and with internal legal services (Argyres and Mayer, 2007). Thus, except when organizational members who interact with external knowledge sources are completely identical to those who can apply this knowledge to opportunity exploitation, the relevant knowledge will have to be communicated to the other units, departments, and persons involved in opportunity exploitation.

Communication with external parties may not occur spontaneously. Firms may have to actively encourage their employees to seek external knowledge that is useful for opportunity exploitation and to disseminate that knowledge internally (Matusik, 2002). However, the firm's organizational design should also reflect the need for timely information processing and knowledge transfer (Tushman and Nadler, 1978). Specifically, firms need to develop coordination devices (e.g., cross-functional teams, liaison groups, and cross-divisional communication channels) that ensure the coordination of the use of knowledge gained from external sources in opportunity exploitation. Thus, decentralization and coordination are complementary organizational practices that are useful for efficiently accessing and deploying external knowledge in the context of realizing strategic opportunities. Therefore, we hypothesize:

Hypothesis 3: There is a three-way interaction between the firm's use of external knowledge sources, decentralization, and coordination, which implies that the positive association between external knowledge sources and opportunity exploitation is strongest when both decentralization and coordination are high.

\section{METHOD AND DATA}

\section{Sampling frame, research instrument, and data collection}

Our study's sampling frame consisted of 3,409 firms, which corresponded to the population of Danish firms with more than 40 employees in 2009. This cut-off point was chosen to balance the exclusion of smaller firms with the need for a sufficiently large sampling frame. Smaller firms may 
have less-developed formal organizational designs (e.g., in terms of hierarchical structure and diversified departments). Thus, the cut-off point is explained on our focus on well-defined organizational design variables. In order to capture inter-industry variability, the sample frame was not restricted to a given industry. Data collection, which relied on a survey administered by Statistics Denmark, began at the end of October 2009 and ended on December 17, 2009.

In order to increase the accuracy of the data and reduce potential common method variance, we adopted a double-respondent questionnaire design. Thus, two different questionnaires, predominantly based on existing scales, were sent to each firm. The first questionnaire contained questions that broadly covered the firm's organizational design and HR policies (e.g., number of hierarchical levels, training and promotion policies, and decision authority). The second included questions about the firm's entrepreneurial activities, and other items that covered firm-level strategic and entrepreneurial variables (e.g., number of discovered opportunities, evaluation criteria, and entrepreneurial orientation). Prior to sending out the questionnaires, Statistics Denmark pilot-tested them with five CEOs and five HR managers. These pre-tests resulted in minor revisions of the original questionnaires.

Initially, the names and email addresses of potential respondents were collected. This made it possible to directly email a message containing an internet link and a password to each potential respondent. The first questionnaire was addressed to the firm's executive HR manager, while the second targeted the firm's most senior executive (e.g., CEO/president). Firms that did not respond to the first request received two mail reminders. In those cases where the reminders were unsuccessful, telephone interviews were attempted in order to increase the response rate.

In total, 1,234 and 897 questionnaires were returned by HR managers and senior executives, respectively. Hence, the response rate for the senior-most executives was $26.3 \%$, while it was $36.2 \%$ for HR managers. These response rates compare favorably to other studies targeting firms' senior management (e.g., Covin, Green, and Slevin, 2006; Zahra and Covin, 1995). In total, questionnaires 
were returned from both the CEO and the HR executive of 628 firms (out of the possible 3,409), resulting in a double-respondent response rate of $18.4 \%$. However, we removed 92 of the double responses from the sample because of missing answers. Thus, the final sample included complete data from 536 firms.

General firm characteristics and balance sheet data were collected from secondary data sources available from Statistics Denmark. The firms in the sample had an average of 238.4 employees (S.D. =797.36). Comparison tests were conducted to establish whether the cleaned sample systematically differed from the non-respondent firms. No significant differences were found at conventional levels in terms of firm age, size, equity, or return on assets. We also tested whether early respondents differed significantly from late respondents in the study's key variables. No significant differences were found for opportunity recognition or exploitation, coordination, decentralization, or external knowledge sources. Consequently, we concluded that the sample accurately represented the population from which it was drawn.

\section{Measures and validation}

Most measures used in this study were adapted from the extant literature. For the multi-item measures, we calculated Cronbach's alpha to establish their internal consistency. In addition, we performed confirmatory factor analysis to examine and validate the reliability of our knowledge sources measure. Our analysis included one dependent variable, three independent variables, and multiple control variables.

\section{Dependent variable}

Opportunity exploitation. The dependent variable was measured as a self-reported count variable. Respondents were asked to report the number of new business opportunities that their firms had successfully realized in the previous three years. Opportunity recognition (e.g., Shepherd and DeTienne, 2005; Westhead, Ucbasaran, and Wright, 2009; Ucbasaran, Westhead, and Wright, 2009) and opportunity exploitation (e.g., Pérez-Luño, Wiklund, and Cabrera, 2011) have previously been 
measured using self-reported counts. To safeguard against respondents implicitly equating new opportunities only with new products, we asked them to report on three different types of opportunities: (1) new products and/or services, (2) production technology, and (3) markets. Thus, we constructed an overall measure as the sum of the number of the opportunities exploited.

Past studies of firm innovativeness have consistently found that the exploitation of opportunities is associated with higher firm performance (e.g., Rauch, Wiklund, Lumpkin, and Frese, 2009). Likewise, absorptive capacity research emphasizes firms' access to new knowledge that promotes innovation (e.g., Cohen and Levinthal, 1990; Zahra and George, 2002). These observations suggest that firms that exploit opportunities will fare better than firms that fail to do so. Yet, exploiting an opportunity is not synonymous with high performance; rather, opportunity exploitation is one of the mechanisms that firms use to improve their performance. As a result, we asked respondents to report on successful exploitation, which we defined in the survey as those opportunities that had 'contributed to improve financial performance.'

\section{Independent variables}

Knowledge sources. We have proposed that external knowledge sources are positively associated with opportunity recognition and with exploitation. To capture external knowledge sources, we used a five-item measure, covering knowledge obtained from: (1) consultants, commercial laboratories, or public $\mathrm{R} \& \mathrm{D}$ units that provide assistance to firms in the R\&D process; (2) conferences, trade fairs, or exhibitions; (3) scientific journals or trade/technical publications; (4) industry associations; and (5) online communities. Our knowledge sources construct included sources that were not directly related to the firm's end-market, which is consistent with our emphasis on opportunity exploitation rather than recognition. Though competitors and customers may be useful sources of external knowledge in opportunity recognition, they are often less useful when it comes to the exploitation of that knowledge. 
Our measure of knowledge sources was based on items found in the Eurostat Community Innovation Survey, which has been widely used in the literature (e.g., Laursen and Salter, 2006; Mairesse and Mohnen, 2002; Veugelers and Cassiman, 1999) and includes a wide variety of external knowledge sources. Our questionnaire included five external sources of knowledge that are considered highly important in opportunity exploitation in terms of testing, organizing, and streamlining processes. For example, conferences, trade fairs, industry associations, exhibitions, and online communities may serve as testing grounds for the marketing aspects of exploitation. Furthermore, consultants assist in organizing and streamlining processes, while commercial laboratories and private $R \& D$ institutes may help with product testing, certification, eliminating bottlenecks, and other such activities.

The survey asked respondents to use a four-point scale ('not used,' 'low,' 'medium,' and 'high') to indicate the extent to which they had searched for knowledge and information from each knowledge source over the three previous years $(\alpha=0.63)$. As the use of external knowledge sources in the process of opportunity exploitation has received little attention in the literature and given the marginal alpha coefficient, we examined the robustness of our knowledge sources measure using confirmatory factor analysis. The results suggested acceptable reliability, with a value of 0.94 for the comparative fit index value, a value of 0.08 for the root mean square error of approximation, a value of 0.04 for standardized root mean square residual, and a value of 0.05 for the CI. These results indicated that our measure had acceptable psychometric properties.

Decentralization. As explained earlier, decentralization refers to the distribution of decisionmaking authority in an organization. Consistent with this definition, respondents were given a list of ten tasks and asked to indicate the organizational level at which decision authority for each task was vested. The highest level of decentralization was coded 4 and denoted 'lower level management (e.g., functional managers, plant managers, regional managers, division managers).' Conversely, the lowest level of decentralization (i.e., high centralization) was coded 1 and denoted 'top management 
(e.g., executive director, deputy director)' (Miller and Dröge, 1986). The ten tasks were: (1) developing new products or services, (2) making major changes in marketing activities, (3) prioritizing projects within the department, (4) cooperating with other units in the firm, (5) collaborating with external firms or organizations, (6) deciding which new projects to pursue in the department, (7) making quality-control decisions, (8) making significant changes in product and services, (9) making major changes in the department's routines, and (10) discontinuing a major product or service. As we were interested in developing a firm-wide measure of decentralization, we created an average composite measure using responses to the ten items $(\alpha=0.83)$. Thus, the higher the value of the average composite decentralization measure, the more decentralized the firm's decision making authority was on average.

Coordination. We measured coordination using seven items derived from O’Donnell (2000). The survey asked respondents to rate each item on a seven-point scale that indicated how often each item was used, with responses ranging from 'never or very rarely' (coded 1) to 'very often' (coded 7). Thus, a higher value indicated that the firm relied more on a certain coordination mechanism. The seven items sought to capture formal/informal and permanent/temporary coordination mechanisms. The items included were: (1) formal committees involving leaders from different departments, (2) temporary cross-functional work groups (task forces), (3) liaison committees, (4) permanent teams across functions, (5) informal personal contacts between managers from different departments, (6) temporary transfers of managers to different functional areas/departments, and (7) internal rotation of highly skilled employees to other departments. Responses to the seven items were averaged to produce a firm-wide average measure of coordination $(\alpha=0.77)$.

\section{Control variables}

Engaging with external knowledge sources during firms' recognition phase increases the number of new opportunities recognized (e.g., Chesbrough, 2003; Laursen and Salter, 2006; Nambisan and Swahney, 2007; Foss, Laursen, and Pedersen, 2011), which may impact on the 
exploitation phase. Thus, to examine the effect of external knowledge sources distinctly in terms of firms' exploitation phase requires that indirect effects, stemming from the recognition phase, are partialled out (Cohen et al., 2003).

Before a firm can exploit an opportunity, the opportunity has to be recognized. Thus, a firm's ability to recognize new opportunities is likely to affect the number of opportunities that are ultimately exploited. Intuitively, more readily exploitable opportunities are likely to prompt the firm to increase its focus on exploitation. However, a large stock of opportunities 'in the pipeline' may also overwhelm an organization; high levels of opportunity recognition may even lead to reduced opportunity exploitation (Pierce and Aguinis, 2011).

While the exact relationship between opportunity recognition and exploitation may be ambiguous, if not properly accounted for this relationship may fundamentally confound our analysis. Although our data does not enable us to determine the specific extent to which firms engage with external sources during the recognition phase, it allows us to separate the indirect effects from the direct effect of firms' engaging with external knowledge sources during exploitation by means of control variables.

Specifically, controlling for the number of opportunities recognized by the firm in the previous three years ensures that variations in the firm's recognition phase, possibly affected by engagement with external knowledge source, are partialled out (Cohen et al., 2003). Essentially, the effect of engaging in external knowledge sourcing during the recognition phase is captured by our control variable, which is then held constant in terms of opportunity exploitation. Partialling out the influence of opportunity recognition ensures that the effect of external knowledge sources on opportunity exploitation lies beyond the recognition phase. To ensure consistency, the control variable comprised the sum of new opportunities recognized based on the same categorization of opportunities as the study's dependent variable. Although we collected data on both opportunity recognized and exploited, the reported opportunities are not necessarily temporally matched. An 
opportunity exploited in the past three years may have been recognized in an earlier time period. Thus, we were unable to construct a meaningful, temporally matched ratio measure of firms' opportunity exploitation. This difficulty is understandable because not all recognized opportunities are exploited and not all exploited opportunities are commercially successful. As our dependent variable counts opportunities that have been successfully exploited, it does not account for mechanisms linking firms' general exploitation intensity and successful exploitation. For instance, the probability of successfully exploiting an opportunity may depend on the total number of opportunities exploited. Moreover, the exploitation of a higher proportion of recognized opportunities provides valuable knowledge and learning opportunities (e.g., Covin et al., 2006; Cope, 2010). Indeed, even unsuccessful exploitation may generate knowledge essential for future entrepreneurial initiatives (Shepherd, 2003). To account for the fact that some firms may, ceteris paribus, exploit a higher proportion of recognized opportunities, we control for the firm's exploitation frequency. This control variable measures the proportion of opportunities that are ordinarily (typically) successfully or unsuccessfully exploited by the firm. Specifically, firms were asked to assess whether 0 percent, 1-20 percent, $21-40$ percent, $41-60$ percent, $61-80$ percent, or 81-100 percent of the business opportunities they evaluated were eventually exploited.

Moreover, 'who' recognizes the opportunity is also likely to influence exploitation activities. Exploitation requires a significant commitment of resources and time. As such, the decision to exploit an opportunity can have significant implications. Opportunities recognized by top-level management have a certain 'pedigree' and may be more likely to be selected for exploitation, for example, as the consequences of failure may be viewed as less severe. In addition, lower-level managers may be more averse than higher-level management to rejecting an opportunity recognized by the CEO because of the asymmetry of power in the hierarchy. Accordingly, we included a binary dummy variable of whether identification of new business opportunities primarily happens at the 
senior management/corporate level in our analyses. The variable was coded 1 if respondent answered 'yes' and 0 otherwise.

Several other factors may influence a firm's ability to exploit strategic opportunities. Thus our analyses included a number of control variables that may generally influence exploitation. Internal $R \& D$ facilities may influence the number of new opportunities a firm can exploit and the firm's ability to source knowledge (Roper et. al., 2008). R\&D influences firms' absorptive capacity (Cohen and Levinthal, 1990: Roper et. al., 2008) and R\&D personnel play a direct role in spanning boundaries to external knowledge sources (Allen, 1977). As a result, our analyses included a dummy variable indicating whether the firm had internal $R \& D$ facilities.

A control variable for firm size, measured as the number of employees, was also included in the analyses. Firm size may influence key organizational characteristics, systems, or processes (Koberg, Uhlenbruck, and Sarason, 1996), as well as entrepreneurial outcomes (e.g., Parker, 2006). We also controlled for firm age, as younger firms have been found to be more innovative than older, more established firms (Hannan and Freeman, 1984).

As our sample contained firms from different industries, we included industry dummies to control for potential confounding effects. Controls were based on ISIC level 1 industry codes and included: (a) manufacturing (used as baseline category), (b) construction, (c) transportation and storage, (d) accommodation and food service activities, (e) information and communication, (f) financial and insurance activities, (g) professional, scientific, and technical activities, and (h) administrative and support service activities.

Finally, we controlled for the state of the global and local markets during our sampling period by measuring the effect of the financial crisis in general terms: Respondents were asked to indicate the extent to which 'the firm's strategy has been influenced by the financial crisis.' Answers ranged from 1 ('to a very little degree') to 7 ('to a very high degree').

\section{Statistical method and analysis}


Table 1 displays the descriptive statistics and inter-correlations for the study's relevant variables. Over a three-year period, the firms in the sample reported that they successfully exploited an average of 9.2 new opportunities. In the same period, firms recognized 13.3 new opportunities on average. The difference between the two numbers is explained by the fact that only some recognized opportunities are selected for exploitation during the evaluation process. Moreover, as our dependent variable measured successful exploitation, some recognized opportunities may have survived the evaluation phase, but were then unsuccessfully exploited (i.e., they failed to contribute to the firm's financial performance).

The correlation matrix does not indicate high collinearity among the main variables except for the relatively high correlation ( 0.79$)$ between the recognition and exploitation of opportunities. However, this correlation is to be expected given the causal mechanism between these two variables.

[Insert Table 1 here]

As our dependent variable (opportunity exploitation) included counts/measures, we used a negative binomial regression analysis. A Poisson regression was also considered. However, because our dependent variable indicated overdispersion (mean of 9.19, S.D. of 19.43), we rejected this alternative. Hierarchical entry of the independent variables was used in the regression models. We started with a base model in which only the controls were included, while the main effect of the independent variables was added in the second model. The third model included two-way interaction terms. As recommended in the literature, this model included all possible two-way interactions (Allison, 1977). The three-way interaction term was entered in the full model (Model 4).

\section{RESULTS}

Our analyses relied on self-reported measures of firms' opportunity exploitation. All models included controls for industry sectors (with the manufacturing sector serving as the baseline), firm age, size, top-level management's recognition of new opportunities, exploitation frequency, the financial crisis, R\&D facilities, and the number of recognized opportunities. The independent 
variables (i.e., knowledge sourcing, coordination, and decentralization) were included in a stepwise manner. As Models 2 and 3 (in Table 2) included interaction terms, all non-binary independent variables were mean centered and variance inflation factors (VIF) were calculated. Average (1.3) and independent VIF scores (1.1-1.7) did not indicate multicollinearity.

\section{[Insert Table 2 here]}

\section{Tests of the hypotheses}

Table 2 presents the results of the hierarchical regression analysis. Coefficient estimates are reported (standard errors in parentheses). Model 1, which only includes the control variables, serves as the baseline model.

Consistent with Hypothesis 1, knowledge sourcing has a positive, significant effect on opportunity exploitation, as shown in Model 2. In Model 3, the interactions between coordination and knowledge sourcing, decentralization and knowledge sourcing, and coordination and decentralization are added. As the parameter estimate for the interaction between decentralization and knowledge sourcing is insignificant, Hypothesis 2 (i.e., that delegation positively moderates the relation between external knowledge sources and opportunity exploitation) is rejected. Although speculative, the lack of support for a moderating relationship between delegation, the use of external knowledge sources, and opportunity exploitation may indicate that delegation is not helpful in the absorption of all types of incoming knowledge. For example, complex, 'architectural' chunks of external knowledge may require coordinated absorption efforts among several departments and functions in a firm. The absorption of such knowledge may be compromised by the strong delegation of decision rights. Thus, delegation may have both negative and positive moderating effects that may cancel each other out. This possibility should be empirically examined in future research.

Table 2 shows that coordination and decentralization in combination have a strong negative ( $\mathrm{p}$ $<0.001)$ effect on opportunity exploitation. One possible explanation is that as decentralization increases, opportunity exploitation activities are carried out by a larger number of specialized 
organizational units. These units often develop specialized knowledge and routines related to particular opportunities, making spontaneous lateral coordination difficult. Furthermore, as exploiting an opportunity usually involves the commitment of significant time and resources, different organizational units may compete, rather than cooperate, for these resources. Lastly, as decentralization increases the hierarchical span of coordination is likely to increase as well. In a highly decentralized structure, coordination must occur across multiple hierarchical levels and is likely to involve more decision makers. Thus, the resulting organizational costs may restrict opportunity exploitation.

Finally, Model 4 includes the hypothesized three-way interaction term for coordination, decentralization, and knowledge sourcing. As Table 2 indicates and consistent with Figure 1, there is a positive and significant effect $(\mathrm{p}<0.05)$, which supports Hypothesis 3. A likelihood ratio test was performed to assess the improvement in the model fit between the hierarchical steps. The results show that all steps (from one model to the next) result in a significantly better fit. Moreover, the slope where knowledge sources, coordination, and decentralization are all high, and the slope where all are low are both positive and significantly different from zero $(\beta=0.85, \mathrm{p}<0.001$ and $\beta=0.61, \mathrm{p}$ $<0.01$, respectively). This supports Hypothesis 3 and indicates the existence of a configurational relationship between decentralization, coordination, and external knowledge sources in general. To aid in the interpretation of our results, Figure 2 illustrates the combined effect of coordination, decentralization, and knowledge sourcing on firms' opportunity exploitation.

[Insert Figure 2 here]

Figure 2 suggests that the marginal effect of external knowledge on opportunity exploitation is strongest when the levels of knowledge sourcing, coordination, and decentralization are all high. Consequently, we conducted slope difference tests to determine whether individual slopes were statistically different from each other (Dawson and Richter, 2006). Typically, high/low test values are set at one standard deviation above and below the mean value. At these values, we were unable to 
statistically differentiate the slopes. However, as a function of complex interactions of more than one pair of slopes, significance tests based on the partial correlation between the product term and the outcome are severely challenged by a substantial reduction in statistical power (Aiken and West, 1991; Dawson and Richter, 2006; Cohen et al., 2003). Still, the two positive and significant slopes indicate that there is a configurational relationship between decentralization, coordination, and knowledge sources. A plausible explanation for the positive relationship between low decentralization, low coordination, and high knowledge sourcing may simply be that because highly centralized knowledge sourcing involves focused contact with designated external knowledge sources, there is little need for formal coordination of those activities throughout the firm.

\section{Sensitivity analyses}

We ran sensitivity analyses to establish the robustness of our results. Given the high correlation between opportunity recognition and exploitation, we reexamined the hypothesized relationship without controlling for the number of opportunities recognized by the firm. Overall, the results did not change substantially, and both the three-way interaction $(\beta=0.46, \mathrm{~S} . \mathrm{E}=0.20, \mathrm{p}=0.03)$ and the direct effect $(\beta=0.44, \mathrm{~S} . \mathrm{E}=0.19, \mathrm{p}=0.02)$ remained significant.

Industry type may also influence the knowledge sources used by the firm and the types of opportunities exploited. Thus, to test for the potential confounding effects of industry type, we used logistic regression analysis with a binary dummy variable code of 1 for early respondents and 0 for late respondents. The independent variables included the eight industry controls and all other variables from our final model. None of the industry controls significantly predicted whether firms were early or late respondents. Furthermore, we reran the analyses on the two largest industries in our sample. The results showed that the direction and strength of the hypothesized associations between knowledge sources, organization design, and opportunity exploitation were similar to those for the full sample but not always significant (manufacturing industry: knowledge sources $\beta=0.37$, S.E $=0.23, p=0.11$, three-way interaction $\beta=0.95, \mathrm{~S} . \mathrm{E}=0.34, \mathrm{p}=0.006$; construction industry: 
knowledge sources $\beta=0.39, \mathrm{~S} . \mathrm{E}=0.27, \mathrm{p}=0.16$, three-way interaction, $\beta=0.10, \mathrm{~S} . \mathrm{E}=0.28, \mathrm{p}=$ 0.72). An analysis of three-way interactions requires large, reliable samples (Aiken and West, 1991; Dawson and Richter, 2006). Thus, our insignificant results were most likely the result of the drop in statistical power caused by the dichotomization of our sample.

Fit statistics were also calculated to compare the original full-sample, negative binomial regression model to a Poisson regression. The results showed that the negative binomial model had a significantly better fit than a Poisson regression model. In addition, as the dependent variable contained a relatively large amount of zeroes, we compared actual zeroes with model-predicted zeroes. The difference was lower in the negative binomial regression than the Poisson regression (0.00 and 0.08 , respectively). These overall results show that the sensitivity analyses were only marginally different from our main results, and provide support for the main effect of knowledge sourcing on opportunity exploitation and the hypothesized three-way interaction.

Finally, we specifically designed our survey instrument to reduce the problem of common method variance. In particular, opportunity exploitation was measured in the questionnaire addressed to the firms' senior-most executive manager. Independent variables were constructed based on data obtained from the senior HR manager (coordination and decentralization) and the executive manager (knowledge sourcing) questionnaire. Controls were measured using secondary data (firm age, size, and industry) and items reported in the questionnaires. The diversity in these data sources reduces the likelihood of common method bias.

\section{CONCLUDING DISCUSSION}

\section{Contributions to theory}

Much knowledge-based research has suggested that firms access external knowledge in order to deploy such knowledge in the context of innovation (Cohen and Levinthal, 1990; Zahra and George, 2002; Laursen and Salter, 2006; Foss et al., 2011). However, there is more to strategic opportunities than (product) innovation-new markets, sources of supply, organizational designs, 
etc., can also be seen as strategic opportunities (Schumpeter, 1912). Moreover, extant knowledgebased research is not forthcoming with respect to whether contact with external knowledge sources also takes place during the process of realizing strategic opportunities or simply ceases once useful knowledge has been absorbed by the firm for the purpose of opportunity recognition (cf. also West and Bogers, 2013).

In this study, we have examined the role of external knowledge sources in the realization of strategic opportunities, and how a firm's organizational design may facilitate interaction with outside knowledge sources in this process. Our analyses show that as firms' reliance on external knowledge sources increases, they exploit more strategic opportunities. This suggests that tapping into external knowledge sources may not only help firms to recognize new opportunities (Shane and Venkataraman, 2000; Venkataraman, 1997), but also to exploit them.

An important insight from our study centers on the role of organizational design in facilitating a firm's use of external knowledge sources in opportunity exploitation. The positive effect of the combination of high coordination, decentralization, and knowledge sourcing on opportunity exploitation is supported by the significant three-way interaction term, which is consistent with Figure 1. This finding reflects the necessity of the right organizational design if a firm is to absorb knowledge from external sources when innovating or exploiting opportunities. Such a design simultaneously emphasizes decentralization and coordination devices (Mendelson, 2000; Foss et al., 2011). Our results suggest that such an organizational setup is also necessary for successfully interacting with external knowledge sources when exploiting opportunities. Thus, the same organizational designs that increase interactions with external knowledge sources that facilitate opportunity recognition are also useful in opportunity exploitation. Thus, at least in a context where external knowledge sources are vital to the entrepreneurial process, structural organizational ambidexterity may not be a major issue (Simsek, 2009). This possibility should be examined in future research. 
The above observations reinforce the vital role of organizational design in seizing the benefits of interacting with diverse knowledge sources for opportunity exploitation (Figure 1). Even though researchers have acknowledged the value of organizational design for opportunity exploitation, our results indicate that design is crucial for capturing, processing, and sharing knowledge in ways that could promote the exploitation of strategic opportunities, reinforcing the propositions of the KBV. As such, our findings clarify an important but often overlooked mechanism through which companies could gain an advantage when they interact with external sources of knowledgeorganizational design (Grant, 1996; von Hippel, 2005).

\section{Limitations and future research}

This study's findings should be considered in light of its limitations. First, the findings are based on cross-sectional data and, as a result, we cannot establish causality. We have argued that interacting with external knowledge sources is positively associated with opportunity exploitation (when we control for opportunity recognition) and that increased interactions with external knowledge sources, and higher levels of coordination and decentralization are positively associated with exploitation. While it seems logical to reason causally from external knowledge sources and organizational design to opportunity exploitation, it is also possible to offer alternative interpretations of our findings.

For example, consistent with the KBV (Eisenhardt and Santos, 2001), an intense focus on exploitation may affect firms' organizational designs and not vice versa. Likewise, high exploitation may increase firms' end-market portfolios to such an extent that increased decentralization is needed to capitalize on managerial capacity. Additional research using longitudinal and/or experimental designs may be useful in clarifying causality among this study's variables.

Our exclusive focus on the role of external knowledge sourcing during opportunity exploitation also affects our empirical analysis. First, our analysis treats opportunity recognition and exploitation as fully distinguishable and wholly contained phases. While this allows us to econometrically isolate 
the effect of external knowledge sourcing on opportunity exploitation from its effect on opportunity recognition (e.g., Laursen and Salter, 2006; Foss, Laursen, and Pedersen, 2011), it excludes timing issues within phases. Thus, effects stemming from when during exploitation the firm taps external knowledge sources are not addressed in our analysis. Moreover, we do not distinguish between whether external knowledge sources are only engaged during exploitation or are carried over from the recognition phase. Although these are certainly important issues, we are confident that in highlighting the important role played by external knowledge sources in opportunity exploitation, we have provided an initial stepping-stone for future research.

Furthermore, we were unable to statistically differentiate between the two significant threeway interaction slopes (i.e., where knowledge sources, coordination, and decentralization are all high or all low). High and low test values may be chosen based on available data and the focal research question (Aiken and West, 1991; Cohen et al., 2003). However, given our sample, we were unable to reexamine the interaction using alternative test values. Thus, we encourage future empirical examinations using different measures of opportunity exploitation and, possibly, left-skewed samples.

We also reiterate that our measure of opportunity exploitation only includes opportunities that were successfully exploited. While we mitigate concerns about survivor bias by controlling for firms' overall exploitation frequency, future refined exploitation measures should keep such a potential bias in mind. Moreover, refinement should strive to account for different type of opportunities, timing issues, and the effect of different modes of exploitation-all factors that are salient in appropriating entrepreneurial rent from opportunities (Teece, 1986).

In addition, given that the sample only included Danish firms, issues regarding the generalizability of the findings to other settings may arise. Empirical analyses using data from other populations and geographical settings are needed to validate and generalize the positive association between the use of external knowledge sources and opportunity exploitation. 
Finally, future empirical research could help in validating our assumptions about the need for interaction between firms receiving knowledge and external sources of knowledge, and the content and frequency of these interactions. Given that firms often use multiple sources to gain access to external knowledge (Nambisan and Swahney, 2007), how they develop, sustain, and manage those interactions could influence the process of opportunity exploitation. Thus, firms may differ with respect to whether they prefer essentially market-based relations or more long-term relations with the same external sources of knowledge. Relatedly, the antecedents of the extent to which firms make use of external knowledge during the process of opportunity exploitation and what explains the form the interaction takes warrant research interest. For example, it may be that strategic opportunities that are particularly novel and complex may necessitate more and longer-term interaction with external knowledge sources.

\section{Conclusion}

Firms have long tapped different external sources of knowledge to develop new products, processes, systems, and business models. These external knowledge sources help to create strategic opportunities that firms can exploit and thereby gain competitive advantages. We have applied the KBV to propose that the use of different external sources of knowledge can help firms recognize and exploit different types of opportunities, and particularly that external knowledge sources are not only important in the context of recognition but also in the context of exploitation. Our analyses support this proposition while underscoring the vital role of organizational design.

Our study adds to the literature by highlighting the process of opportunity exploitation and the vital role of organizational design in this process. This does not imply the supremacy of organizational design relative to the firm-specific capabilities that have traditionally been central in the KBV (Eisenhardt and Santos, 2001), but it reinforces our study's focus on the role of organizational design. Companies need integrative capabilities in order to combine and use different types of knowledge (Kogut and Zander, 1992). They also need the capability to craft new visions for 
their ecosystems, industries, and markets (Nambisan and Swahney 2007). Furthermore, they must develop strategies that exploit opportunities by using newly created (or acquired) knowledge (Zahra and George, 2002). We argue that external knowledge sources continue to play a role in these processes and are not limited to an initial phase of opportunity recognition. Moreover, these issues support our focus on the role of an organization design in which middle and senior managers interact to create momentum for crafting new strategies, revising strategic priorities, or building different capabilities. We hope our results encourage more research on the exploitation of strategic opportunities, and on how firms develop effective organizational designs that enable them to benefit from their interactions with and use of different external sources of knowledge.

\section{REFERENCES}

Ahuja G, Lampert CM. 2001. Entrepreneurship in the large corporation: a longitudinal study of how established firms create breakthrough inventions. Strategic Management Journal 22: 521-543.

Aiken, L. S., West, S. G. 1991. Multiple regression: Testing and interpreting interactions. Sage: Newbury Park, CA.

Aldrich H, Herker D. 1977. Boundary spanning roles and organization structure. The Academy of Management Review 2: 217-230.

Allen TJ. 1977. Managing the Flow of Technology: Technology Transfer and the Dissemination of Technological Information with the RandD Organization. MIT Press: Cambridge, MA.

Allen TJ, Cohen SI. 1969. Information flow in research and development laboratories. Administrative Science Quarterly 14: 12-19.

Allison PD. 1977. Testing for interaction in multiple regression. American Journal of Sociology 83 : 144-153.

Arora A 1996. Contracting for tacit knowledge: the provision of technical services in technology licensing contracts. Journal of Development Economics 50: 233-256.

Audretsch DB, Keilbach M. 2007. The theory of knowledge spillover entrepreneurship. Journal of Management Studies 44: 1242-1254.

Autio, E 1997. New, technology-based firms in innovation networks symplectic and generative impacts. Research Policy, 26: 263-281.

Audretsch DB, Lehmann EE, Warning S. 2005. University spillovers and new firm location. Research Policy 34: 1113-1122.

Baldwin C, Clark KB. 2000. Design Rules. MIT Press: Cambridge, MA.

Birkinshaw J. 1997. Entrepreneurship in multinational corporations: the characteristics of subsidiary initiatives. Strategic Management Journal 18: 207-229. 
Brandenburger AM, Stuart HW. 1996. Value-based business strategy. Journal of Economics and Management Strategy 5: 5-24.

Burns T, Stalker GM. 1961. The Management of Innovation. 1994 reissue. Oxford University Press: Oxford.

Burton R, Obel B. 1998. Strategic Organizational Diagnosis and Design. Kluwer: Dordrecht, The Netherlands.

Burton, R.M., B. Obel . 2004. Strategic Organizational Diagnosis and Design: The Dynamics of Fit. Kluwer: New York.

Cassiman B, Veugelers R. 2002. RandD cooperation and spillovers: some empirical evidence from Belgium. The American Economic Review 92: 1169-1184.

Chandler AD. 1990. Strategy and Structure: Chapters in the History of the Industrial Enterprise. MIT Press: Cambridge, MA.

Chesbrough H. 2003. Open Innovation. Harvard University Press: Cambridge, MA.

Cohen, J., Cohen, P., West, S. G., Aiken, L. S. 2003. Applied multiple regression/ correlation analysis for the behavioral sciences. Erlbaum: Hillsdale, NJ.

Cohen WM, Levinthal DA. 1990. Absorptive capacity: a new perspective on learning and innovation. Administrative Science Quarterly 35(1): 128-152.

Cooper AC. 1973. Technical entrepreneurship: what do we know? RandD Management 3: 59-64.

Cope J. 2010. Entrepreneurial learning from failure: an interpretative phenomenological analysis. Journal of Business Venturing 26(11): 604-623.

Covin JG, Green KM, Slevin DP. 2006. Strategic process effects on the entrepreneurial orientationsales growth rate relationship. Entrepreneurship Theory and Practice: 57-81.

Dawson, J. F., Richter, A. W. 2006. Probing three-way interactions in moderated multiple regression: development and application of a slope difference test. The Journal of applied psychology 91(4): 917-26.

Denrell J, Fang C, Winter SG. 2003. The economics of strategic opportunity. Strategic Management Journal 24: 977-990.

Dougherty D. 2001. Reimagining the differentiation and integration of work for sustained product innovation. Organization Science 12: 612-631.

Eisenhardt KM, Santos P. 2001. Knowledge-based view: a new theory of strategy? In Handbook of Strategy and Management, Pettigrew AM, Thomas H, Whittington R (eds). Sage: New York; 139-164.

Foss NJ, Klein PG. 2012. Organizing Entrepreneurial Judgment. Cambridge University Press: Cambridge.

Foss NJ, Laursen K, Pedersen T. 2011. Linking customer interaction and innovation: the mediating role of new organizational practices. Organization Science 22: 980-999.

Galbraith JR. 1974. Organization design: an information processing view. Interfaces 4(3): 28-36.

Grant RM. 1996. Prospering in dynamically-competitive environments: organizational capability as knowledge integration. Organization Science 7: 375-387.

Hannan MT, Freeman J. 1984. Structural inertia and organizational change. American Sociological Review 49(2): 149-164. 
Helfat C. 1997. Know-how and asset complementarity and dynamic capability accumulation: the case of RandD. Strategic Management Journal 18: 339-360.

Henkel J, von Hippel E. 2005. Welfare implications of user innovation. Journal of Technology Transfer 30(1/2): 73-87.

Ireland RD, Covin JG, Kuratko DF. 2009. Conceptualizing corporate entrepreneurship strategy. Entrepreneurship Theory and Practice 33: 19-46.

Jackson JH, Morgan CP. 1982. Organization Theory. Prentice-Hall.

Jansen JJP, van den Bosch FAJ, Volberda HW. 2005. Managing potential and realized absorptive capacity: how do organizational antecedents matter? Academy of Management Journal 48(6): 999-1015.

Jensen MC, Meckling WH. 1992. Specific and general knowledge and organizational structure. In Contract Economics, Werin L, Wijkander H (eds). Blackwell: Oxford.

Katila R, Ahuja G. 2002. Something old, something new: a longitudinal study of search behavior and new product introduction. Academy of Management Journal 45: 1183-1194.

Ketchen D, Ireland RD, Snow C. 2007. Strategic entrepreneurship, collaborative innovation, and wealth creation. Strategic Entrepreneurship Journal 1(1): 371-385.

Kirzner IM. 1973. Competition and Entrepreneurship. University of Chicago Press: Chicago.

Kline SJ, Rosenberg N. 1986. An overview of innovation. In The Positive Sum Strategy: Harnessing Technology for Economic Growth, Landau R, Rosenberg N (eds). National Academy Press: Washington, DC; 275-305.

Ko DG, Kirsch LJ, King, WR. 2005. Antecedents of knowledge transfer from consultants to clients in enterprise system implementations. MIS Quarterly 29: 59-85.

Koberg CS, Uhlenbruck N, Sarason Y. 1996. Facilitators of organizational innovation: the role of life-cycle stage. Journal of Business Venturing 11(2): 133-149.

Langlois RN, Robertson PL. 1995. Firms, markets, and economic change : a dynamic theory of business institutions. New York: Routledge.

Laursen K, Salter AJ. 2006. Open for innovation: the role of openness in explaining innovative performance among UK manufacturing firms. Strategic Management Journal 27(2): 131-150.

Leiponen A, Helfat CE. 2010. Innovation objectives, knowledge sources, and the benefits of breadth. Strategic Management Journal 31: 224-236.

Lenox M, King A. 2004. Prospects for developing absorptive capacity through internal information provision. Strategic Management Journal 25: 331-345.

Mairesse J, Mohnen P. 2002. Accounting for innovation and measuring innovativeness: an illustrative framework and an application. Papers and Proceedings of the One Hundred Fourteenth Annual Meeting of the American Economic Association: 226-230

Matusik S. 2002. Managing public and private firm knowledge within the context of flexible firm boundaries. In Strategic Management of Intellectual Capital and Organizational Knowledge, Bontis N, Choo CW (eds). Oxford University Press: Oxford.

Mayer K, Argyres NS. 2004. Learning to contract: evidence from the personal computer industry. Organization Science 15: 394-410.

Mendelson H. 2000. Organizational architecture and success in the information technology industry. Management Science 46(4): 513-529. 
Michael SC. 2003. First-mover advantage through franchising. Journal of Business Venturing 18: 61-80.

Michael SC. 2007. Transaction cost entrepreneurship. Journal of Business Venturing 22: 412-426.

Miller KD, Dröge C. 1986. Psychological and traditional determinants of structure. Administrative Science Quarterly 31: 539-560.

Mol M, Birkinshaw JM. 2009. The sources of management innovation: when firms introduce new management practices. Journal of Business Research 62: 1269-1280.

Monteverde K. 1995. Technical dialog as an incentive for vertical integration in the semiconductor industry. Management Science 41: 1624-1638.

Mueller P. 2006. Exploring the knowledge filter: how entrepreneurship and university-industry relationships drive economic growth. Research Policy 35: 1499-1508.

Nambisan S, Swahney M. 2007. The Global Brain: Your Roadmap for Innovating Smarter and Faster in the Networked World. Wharton Publishing: Upper Saddle River, NJ.

Nelson RR, Winter S. 1982. An Evolutionary Theory of Economic Change. Harvard University Press: Cambridge, MA.

Nickerson J, Zenger T. 2004. A knowledge-based theory of the firm: The problem-solving perspective. Organization Science 15: 617-632.

O'Donnell SW. 2000. Managing foreign subsidiaries: agents of headquarters, or an interdependent network? Strategic Management Journal 21(5): 525-548.

Oviatt BM, MacDougall PP. 2005. Defining international entrepreneurship and modeling the speed of internationalization. Entrepreneurship Theory and Practice 29: 537-554.

Parker SC. 2006. A selection-based theory of the transition from employment to entrepreneurship: the role of employer size. IZA Discussion Paper No. 2071.

Pérez-Luño A, Wiklund J, Cabrera, RV. 2011. The dual nature of innovative activity: how entrepreneurial orientation influences innovation generation and adoption. Journal of Business Venturing 26: 1-17.

Pierce JR, Aguinis H. 2011. The too-much-of-a-good-thing effect in management. Journal of Management [advance online publication; doi: 10.1177/0149206311410060].

Rauch A, Wiklund J, Lumpkin GT, Frese M. 2009. Entrepreneurial orientation and business performance: an assessment of past research and suggestions for the future. Entrepreneurship Theory and Practice 33(3): 761-787.

Richardson, GB. 1972. The organisation of industry. Economic Journal, 82: 883-896.

Roper S, Du J, Love JH. 2008. Modeling the innovation value chain. Research Policy 37: 961-977.

Rumelt RP. 1987. Theory, strategy, and entrepreneurship. In The Competitive Challenge, Teece D (ed). Ballinger: Cambridge, MA;

Schumpeter JA. 1912/1934. The Theory of Economic Development: An Inquiry into Profits, Capital, Credit, Interest and the Business Cycle. Oxford University Press: London.

Shane S. 2000. Prior knowledge and the discovery of entrepreneurial opportunities. Organization Science 11: 448-469.

Shane S, Venkataraman S. 2000. The promise of entrepreneurship as a field of research. Academy of Management Review 25: 217-226. 
Shepherd DA. 2003. Learning from business failure: propositions of grief recovery for the selfemployed. Academy of Management Review 28: 318-328.

Shepherd, D. A., DeTienne, D. R. 2005. Prior Knowledge, Potential Financial Reward, and Opportunity Identification. Entrepreneurship: Theory and Practice 29(1): 91-113.

Simsek Z. 2009. Organizational ambidexterity: towards a multilevel understanding. Journal of Management Studies 46: 597-624.

Teece D.J. 1986. Profiting from technological innovation: implications for integration collaboration, licensing and public policy. Research Policy 15(6): 285-305.

Teece D.J.1992. Competition, cooperation, and innovation: organizational arrangements for regimes of rapid technological progress. Journal of Economic Behavior and Organization 18(1): 1-25

Teece DJ. 1998. Design issues for innovative firms: bureaucracy, incentives and industrial structure. In The Dynamic Firm: The Role of Technology, Strategy, Organization, and Regions, Chandler AD, Hagström P, Sölwall Ö (eds). Oxford University Press: Oxford.

Tushman M, Nadler D. 1978. Information processing as an integrating concept in organizational design. Academy of Management Review 3(3): 613-624.

Tushman ML, Katz R. 1980. External communication and project performance: An investigation into the role of gatekeepers. Management Science 26: 1071-1085.

Ucbasaran D, Westhead P, Wright, M. 2009. The extent and nature of opportunity identification by repeat entrepreneurs. Journal of Business Venturing 24: 99-115.

Venkataraman S. 1997. The distinctive domain of entrepreneurship research. Advances in Entrepreneurship, Firm Emergence and Growth 3: 119-138.

Veugelers R, Cassiman B. 1999. Make and buy in innovation strategies: evidence from Belgian manufacturing firms. Research Policy 28(1): 63-80.

Volberda HW, Foss NJ, Lyles MA. 2010. Absorbing the concept of absorptive capacity: how to realize its potential in the organization field. Organization Science 21(4): 931-951.

von Hippel E. 1976. Dominant role of users in the scientific instrument innovation process. Research Policy 5(3): 212-239.

von Hippel E. 1988. The Sources of Innovation. Oxford University Press: New York and Oxford.

von Hippel E. 1994. 'Sticky information' and the locus of problem solving: implications for innovation. Management Science 40(4): 429-439.

von Hippel E. 1998. Economics of product development by users: the impact of 'sticky' local information. Management Science 44(5): 629-644.

von Hippel E. 2005. Democratizing Innovation. MIT Press: Cambridge, MA.

Westhead P, Ucbasaran D, Wright M. 2009. Information search and opportunity identification: the importance of prior business ownership experience. International Small Business Journal 27: 659-680.

West J, Bogers, M. 2013. Leveraging external sources of innovation: A review of research on open innovation. Journal of Product Innovation Management (forthcoming).

Zahra SA, Covin JG. 1995. Contextual influences on the corporate entrepreneurship-performance relationship: a longitudinal analysis. Journal of Business Venturing 10: 43-58. 
Zahra S, George G. 2002. Absorptive capacity: a review, reconceptualization, and extension. Academy of Management Review 27: 185-203.

Zander U, Kogut B. 1995. Knowledge and the speed of the transfer and imitation of organizational capabilities: an empirical test. Organization Science 6(1): 76-92. 


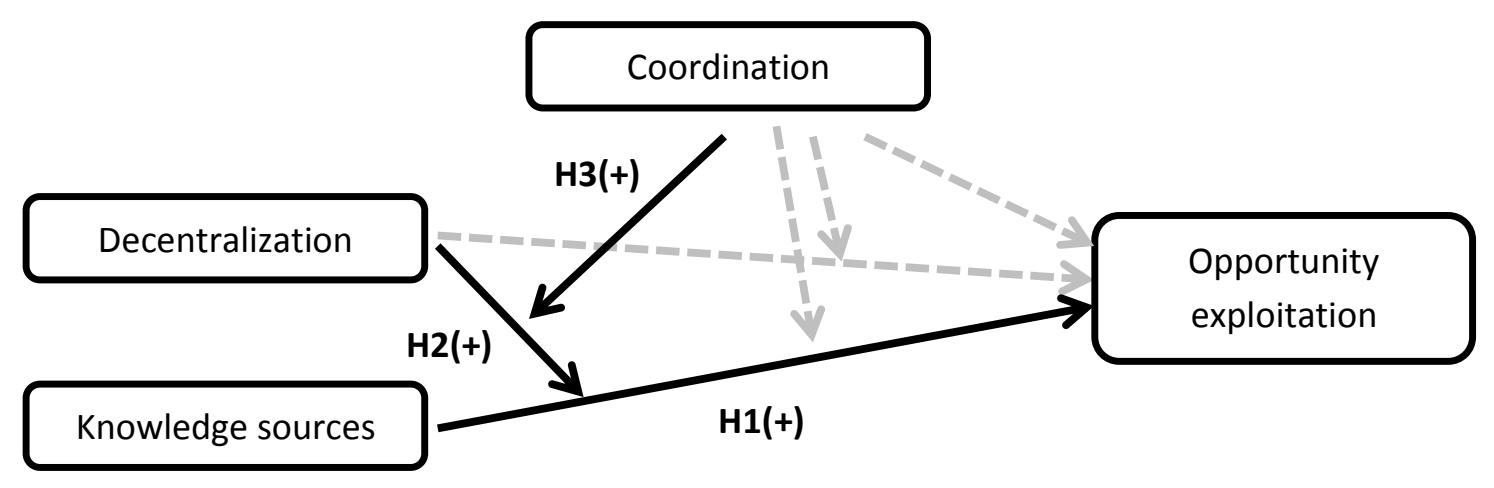

Figure 1: The theoretical model

Full arrows indicate hypotheses. Dotted arrows indicate effects included as controls. 
TABLE 1: DESCRIPTIVE STATISTICS AND CORRELATIONS

\begin{tabular}{|c|c|c|c|c|c|c|c|c|c|c|c|c|c|c|}
\hline \multicolumn{2}{|c|}{ Variables } & \multirow{2}{*}{$\begin{array}{l}\text { Mean } \\
9.19\end{array}$} & \multirow{2}{*}{$\begin{array}{l}\text { S.D. } \\
19.43\end{array}$} & \multirow{2}{*}{ (1) } & \multirow[t]{2}{*}{$(2)$} & \multirow[t]{2}{*}{ (3) } & \multirow[t]{2}{*}{ (4) } & \multirow[t]{2}{*}{$(5)$} & \multirow[t]{2}{*}{ (6) } & \multirow[t]{2}{*}{ (7) } & \multirow[t]{2}{*}{$(8)$} & \multirow[t]{2}{*}{ (9) } & \multirow[t]{2}{*}{$(10)$} & $(:$ \\
\hline (1) & $\begin{array}{l}\text { Opportunity } \\
\text { exploitation }\end{array}$ & & & & & & & & & & & & & \\
\hline$(2)$ & $\begin{array}{l}\text { Knowledge } \\
\text { sources }\end{array}$ & 0.00 & 0.30 & 0.06 & - & & & & & & & & & \\
\hline (3) & Decentralization & 2.34 & 0.51 & $0.14 * *$ & 0.05 & - & & & & & & & & \\
\hline (4) & Coordination & 4.40 & 1.57 & $0.10 *$ & $0.10 *$ & $0.28 * * *$ & - & & & & & & & \\
\hline (5) & R\&D facilities & 0.46 & 0.50 & $0.12 * *$ & $0.15^{* * *}$ & $0.11 * *$ & $0.26 * * *$ & - & & & & & & \\
\hline (6) & Firm size & 238.40 & 797.36 & $0.33 * * *$ & 0.03 & $0.12 * *$ & 0.07 & 0.04 & - & & & & & \\
\hline (7) & $\begin{array}{l}\text { Senior-level } \\
\text { recognition }\end{array}$ & 0.72 & 0.45 & $-0.12 * *$ & $-0.11 *$ & -0.07 & $-0.09 *$ & -0.02 & $-0.12 * *$ & - & & & & \\
\hline (8) & $\begin{array}{l}\text { Opportunity } \\
\text { recognition }\end{array}$ & 13.29 & 22.89 & $0.79 * * *$ & $0.09 *$ & $0.09 *$ & 0.05 & $0.14 * *$ & $0.30 * * *$ & $-0.18 * * *$ & - & & & \\
\hline$(9)$ & $\begin{array}{l}\text { Exploitation } \\
\text { frequency }\end{array}$ & 3.20 & 1.13 & $0.13 * *$ & $0.11 * *$ & $0.10^{*}$ & $0.15^{* * *} *$ & 0.05 & 0.05 & -0.01 & $0.12 * *$ & & & \\
\hline (10) & Firm age & 24.21 & 21.16 & $0.09 *$ & 0.06 & -0.02 & $0.12 * *$ & -0.01 & $0.09 *$ & -0.04 & $0.09 *$ & 0.06 & - & \\
\hline (11) & Financial crisis & 4.42 & 1.90 & $-0.09 *$ & $0.09 *$ & 0.01 & -0.02 & -0.04 & -0.00 & 0.06 & -0.08 & $-\overline{0}$ & 0.04 & - \\
\hline
\end{tabular}


TABLE 2

Hierarchical Negative Binomial Regression Analysis for Opportunity Exploitation

\begin{tabular}{|c|c|c|c|c|}
\hline Variable & Model 1 & Model 2 & Model 3 & Model 4 \\
\hline Knowledge sources & & $\begin{array}{l}0.47 * * * \\
(0.14)\end{array}$ & $\begin{array}{l}0.52 * * * \\
(0.13)\end{array}$ & $\begin{array}{l}0.45 * * * \\
(0.14)\end{array}$ \\
\hline Decentralization & & $\begin{array}{l}0.29 * * * \\
(0.07)\end{array}$ & $\begin{array}{l}0.22 * * \\
(0.08)\end{array}$ & $\begin{array}{l}0.19 * \\
(0.08)\end{array}$ \\
\hline Coordination & & $\begin{array}{l}0.08 * * \\
(0.03)\end{array}$ & $\begin{array}{l}0.08 * * \\
(0.03)\end{array}$ & $\begin{array}{l}0.09 * * * \\
(0.03)\end{array}$ \\
\hline Knowledge sources $\mathrm{x}$ decentralization & & & $\begin{array}{l}-0.02 \\
(0.26)\end{array}$ & $\begin{array}{l}0.14 \\
(0.27)\end{array}$ \\
\hline Knowledge sources $\mathrm{x}$ coordination & & & $\begin{array}{l}0.02 \\
(0.08)\end{array}$ & $\begin{array}{l}0.03 \\
(0.09)\end{array}$ \\
\hline Decentralization $\mathrm{x}$ coordination & & & $\begin{array}{l}-0.19 * * * \\
(0.04)\end{array}$ & $\begin{array}{l}-0.16 * * * \\
(0.05)\end{array}$ \\
\hline $\begin{array}{l}\text { Knowledge sources } \mathrm{x} \text { decentralization } \mathrm{x} \\
\text { coordination }\end{array}$ & & & & $\begin{array}{l}0.36 * \\
(0.15)\end{array}$ \\
\hline Industry b & $\begin{array}{l}-0.25 * \\
(0.12)\end{array}$ & $\begin{array}{l}-0.20 \\
(0.11)\end{array}$ & $\begin{array}{l}-0.21 \\
(0.11)\end{array}$ & $\begin{array}{l}-0.23 * \\
(0.11)\end{array}$ \\
\hline Industry c & $\begin{array}{l}-0.30 \\
(0.17)\end{array}$ & $\begin{array}{l}-0.24 \\
(0.17)\end{array}$ & $\begin{array}{l}-0.23 \\
(0.16)\end{array}$ & $\begin{array}{l}-0.24 \\
(0.16)\end{array}$ \\
\hline Industry d & $\begin{array}{l}-0.60 * \\
(0.24)\end{array}$ & $\begin{array}{l}-0.60 * \\
(0.24)\end{array}$ & $\begin{array}{l}-0.57 * \\
(0.24)\end{array}$ & $\begin{array}{l}-0.62 * \\
(0.24)\end{array}$ \\
\hline Industry e & $\begin{array}{l}-0.35 * \\
(0.15)\end{array}$ & $\begin{array}{l}-0.30 * \\
(0.15)\end{array}$ & $\begin{array}{l}-0.28 \\
(0.15)\end{array}$ & $\begin{array}{l}-0.30 * \\
(0.15)\end{array}$ \\
\hline Industry f & $\begin{array}{l}-0.46^{*} \\
(0.18)\end{array}$ & $\begin{array}{l}-0.51 * * \\
(0.18)\end{array}$ & $\begin{array}{l}-0.51 * * \\
(0.17)\end{array}$ & $\begin{array}{l}-0.51 * * \\
(0.17)\end{array}$ \\
\hline Industry g & $\begin{array}{l}-0.35 * \\
(0.14)\end{array}$ & $\begin{array}{l}-0.39 * * \\
(0.14)\end{array}$ & $\begin{array}{l}-0.37 * * \\
(0.14)\end{array}$ & $\begin{array}{l}-0.40 * * \\
(0.14)\end{array}$ \\
\hline Industry $h$ & $\begin{array}{l}-0.17 \\
(0.18)\end{array}$ & $\begin{array}{l}-0.02 \\
(0.18)\end{array}$ & $\begin{array}{l}-0.10 \\
(0.18)\end{array}$ & $\begin{array}{l}-0.05 \\
(0.18)\end{array}$ \\
\hline R\&D facilities & $\begin{array}{l}0.23 * * \\
(0.09)\end{array}$ & $\begin{array}{l}0.14 \\
(0.09)\end{array}$ & $\begin{array}{l}0.15 \\
(0.09)\end{array}$ & $\begin{array}{l}0.14 \\
(0.08)\end{array}$ \\
\hline Firm size & $\begin{array}{l}-0.00 \\
(0.00)\end{array}$ & $\begin{array}{l}-0.00 \\
(0.00)\end{array}$ & $\begin{array}{l}-0.00 \\
(0.00)\end{array}$ & $\begin{array}{l}-0.00 \\
(0.00)\end{array}$ \\
\hline Top-level opportunity recognition & $\begin{array}{l}0.07 \\
(0.09)\end{array}$ & $\begin{array}{l}0.12 \\
(0.09)\end{array}$ & $\begin{array}{l}0.11 \\
(0.09)\end{array}$ & $\begin{array}{l}0.09 \\
(0.09)\end{array}$ \\
\hline Number of recognized opportunities & $\begin{array}{l}0.03 * * * \\
(0.00)\end{array}$ & $\begin{array}{l}0.03 * * * \\
(0.00)\end{array}$ & $\begin{array}{l}0.03 * * * \\
(0.00)\end{array}$ & $\begin{array}{l}0.03 * * * \\
(0.00)\end{array}$ \\
\hline Exploitation frequency $0 \%$ & $\begin{array}{l}-10.69 * * * \\
(0.41)\end{array}$ & $\begin{array}{l}-10.30 * * \\
(0.42)\end{array}$ & $\begin{array}{l}-10.04 * \\
(0.43)\end{array}$ & $\begin{array}{l}-10.00 * \\
(0.43)\end{array}$ \\
\hline Exploitation frequency $21-40 \%$ & $\begin{array}{l}0.10 \\
(0.10)\end{array}$ & $\begin{array}{l}0.12 \\
(0.10)\end{array}$ & $\begin{array}{l}0.20 \\
(0.10)\end{array}$ & $\begin{array}{l}0.17 \\
(0.10)\end{array}$ \\
\hline Exploitation frequency $41-60 \%$ & $\begin{array}{l}0.41 * * * \\
(0.10)\end{array}$ & $\begin{array}{l}0.38 * * * \\
(0.10)\end{array}$ & $\begin{array}{l}0.43 * * * \\
(0.10)\end{array}$ & $\begin{array}{l}0.42 * * * \\
(0.10)\end{array}$ \\
\hline Exploitation frequency $61-80 \%$ & $\begin{array}{l}0.34 * * \\
(0.13)\end{array}$ & $\begin{array}{l}0.32 * * \\
(0.12)\end{array}$ & $\begin{array}{l}0.36 * * \\
(0.12)\end{array}$ & $\begin{array}{l}0.35 * * \\
(0.12)\end{array}$ \\
\hline Exploitation frequency $81-100 \%$ & $\begin{array}{l}0.08 \\
(0.33)\end{array}$ & $\begin{array}{l}0.04 \\
(0.33)\end{array}$ & $\begin{array}{l}0.11 \\
(0.32)\end{array}$ & $\begin{array}{l}0.08 \\
(0.32)\end{array}$ \\
\hline Firm age & $\begin{array}{l}0.00 \\
(0.00)\end{array}$ & $\begin{array}{l}0.00 \\
(0.00)\end{array}$ & $\begin{array}{l}0.00 \\
(0.00)\end{array}$ & $\begin{array}{l}0.00 \\
(0.00)\end{array}$ \\
\hline Financial crisis & $\begin{array}{l}-0.04 \\
(0.02)\end{array}$ & $\begin{array}{l}-0.04 * \\
(0.02)\end{array}$ & $\begin{array}{l}-0.04 \\
(0.02)\end{array}$ & $\begin{array}{l}-0.03 \\
(0.02)\end{array}$ \\
\hline Intercept & $\begin{array}{l}1.62 * * * \\
(0.12)\end{array}$ & $\begin{array}{l}1.58 * * * \\
(0.12)\end{array}$ & $\begin{array}{l}1.56 * * * \\
(0.12)\end{array}$ & $\begin{array}{l}1.59 * * * \\
(0.12)\end{array}$ \\
\hline Log likelihood & -1490.48 & -1471.87 & -1461.83 & -1459.00 \\
\hline Delta log likelihood & & $18.61 * * *$ & $10.04 * * *$ & $2.83^{*}$ \\
\hline
\end{tabular}

$\mathrm{n}=536 ; * \mathrm{p}<0.05, * * \mathrm{p}<0.01, * * * \mathrm{p}<0.001$ 


\section{FIGURE 2: THREE-WAY INTERACTION WITH OPPORTUNITY}

EXPLOITATION AS DEPENDENT VARIABLE

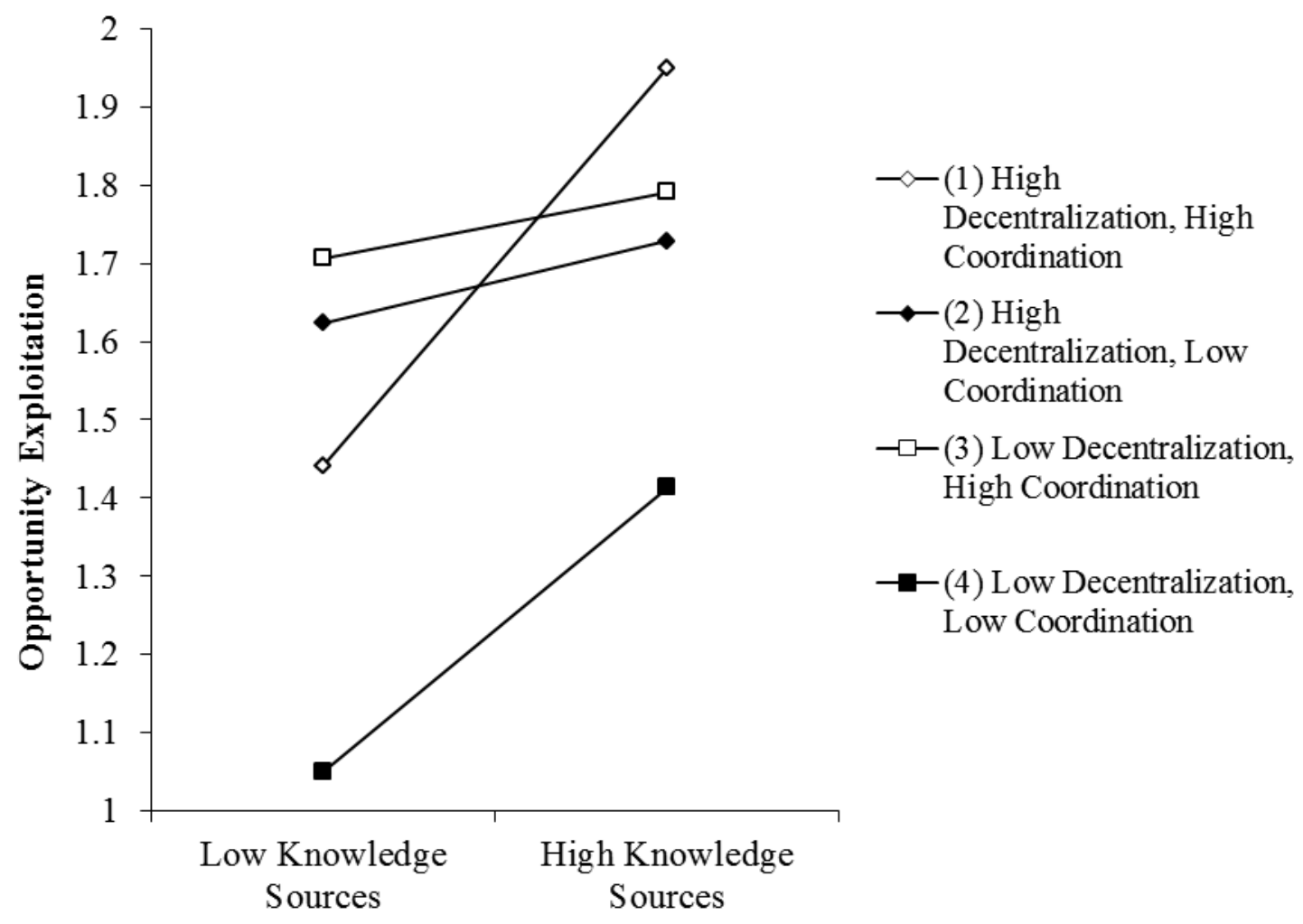

